The body of the corpse had frozen and there was a faint parting of the lips just like George had seen many times when the Indian anticipated a drink of liquor. "Oh, no," thought George, "you've taken your last snort."

Out in the cottonwood grove George shoveled away the snow and with pick and shovel dug a shallow grave. Then he made a trip with a team of horses and sled to Missouri Valley for a casket and rough box. Once in town he got several drinks to warm up. He miscalculated his capacity for drink and his ability to retain his normal senses.

Twice on the way back he upset the sled, spilling out the contents and self. The last time the wagon box turned upside down pinning George, casket and a few groceries beneath. He was found not three hundred yards from home, but very drunk. Another day came before George was in shape to complete the burial. The day was almost spent before the task was finished, amid the wailing of the women and the howling of the dogs.

The sequence of this story is that George lost his Indian sweetheart, as well as the companionship of the Chief. In midwinter, during a brief modulation of weather, the squaw and girls with the old roan horse and travis, all their belongings, including the old delapidated leather tepee, were seen heading toward the ferry. The squaw was leading the roan'nag and the girls and six dogs were trailing behind her.

\title{
FOUNDATION OF OUR INSTITUTIONS
}

Gov. Henry Dodge: The elective franchise of the people is the sacred palladium of our rights, the shield and helmet of our liberties, and the foundation upon which our republican institutions must exist; all should equally participate in the advantage of representation. according to numbers.-Special Session Message, Wisconsin Territorial Assembly, June 11, 1838. 
Copyright of Annals of Iowa is the property of State of Iowa, by \& through the State Historical Society of Iowa and its content may not be copied or emailed to multiple sites or posted to a listserv without the copyright holder's express written permission. However, users may print, download, or email articles for individual use. 